\title{
Sait Halim Paşa'dan Etkilenen Bir İngiliz Yazar ve Düşünür; Marmaduke W. Pickthall
}

\author{
Kemal Kahraman* \\ (ORCID: 0000-0002-5427-9997) \\ Makale Gönderim Tarihi \\ 14.01.2021 \\ Makale Kabul Tarihi \\ 25.03.2021
}

\section{Atıf Bilgisi/Reference Information}

Chicago: Kahraman, K., "Sait Halim Paşa'dan Etkilenen Bir İngiliz Yazar ve Düşünür; Marmaduke W. Pickthall", Vakanüvis-Uluslararası Tarih Araştırmaları Dergisi, 6/1 (2021): 260-288.

APA: Kahraman, K. (2021). Sait Halim Paşa'dan Etkilenen Bir İngiliz Yazar ve Düşünür; Marmaduke W. Pickthall. Vakanüvis-Uluslararası Tarih Araştırmaları Dergisi, 6 (1) , 260-288.

\section{Öz}

Prens Sait Halim Paşa Osmanlı́nın son döneminde önemli görevler almış devlet, düşünce ve kültür adamıdır. Devletin tarihi bir süreçten geçtiği yıllarda belirleyici bir rol aldığı gibi düşünceleri ve yazdıklarıyla ülkemizde ve özellikle İslam dünyasında etkili olmuş, yakından izlenmiştir. Bu çalışma, Sait Halim Paşa'nın fikirlerinden büyük ölçüde etkilenen, Hindistan ve İngiltere'de Müslümanlar arasında tanınmasını sağlayan bir isimde odaklanıyor; Marmaduke W. Pickthall. Sonradan Müslüman olan İngiliz yazar ve edebiyatçı, aile ve düşünce itibariyle İngiltere'deki muhafazakâr geleneğe dayanıyor. Bizzat görüşme imkânı bulduğu Paşa'nın fikirlerinden çok etkileniyor. Yaptı̆̆ı konuşmalarda ve yazılarında onları paylaşıyor. Bir kısmını İngilizceye çevirerek yayınlıyor. Sait Halim Paşa ve Pickthall'ın düşünceleri arasında önemli benzerlikler ve paralellikler söz konusudur.

Anahtar Kelimeler: Meşruiyet, Ingiltere, Mısır, Hidiv, Sait Halim Paşa, Pickthall, İslamcılık, Hilafet, Osmanlı, Hindistan, Birinci Dünya Savaşı, modernleşme, ittihat ve Terakki.

*Dr., TBMM Milli Saraylar, kekahraman58@gmail.com

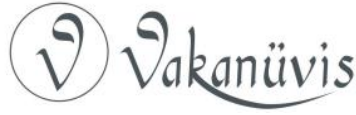




\title{
A British Author and Intellectual Which is Impressed By Said Halim Pasha; Marmaduke W. Pickthall
}

\begin{abstract}
Prince Sait Halim Pasha was a man of state, idea and culture who had very important roles at the last years of the Ottoman Empire. While he played a decisive role at years in which the State was experiencing historical times, he had also been effective and followed closely in our country and at the Islamic World with his ideas and writings. This work is focusing on a man who was strongly affected by the ideas of Sait Halim Pasha and made them known among the Muslims in India and UK; Marmaduke W. Pickthall. As an English writer and man of literature, concerning his family and ideas, he is coming from the conservatist tradition in UK. He was influenced by the ideas of Pasha whom he had opportunity to meet in person at a young age. And reflected them in his later life in his Works and conferences. He has publishes many of them by translating into English. There are important similarities and parallels between the ideas of Sait Halim Pasha and Pickthall.
\end{abstract}

Keywords; Monarchy, UK, Egypt, Khedive, Sait Halim Pasha, Pickthall, İslamism, Caliphate, Ottoman, India, First World War, modernization, Union and Progress.

\section{Mısırlı Bir Paşa}

Osmanlı Devleti'nin son yüzyılına yenileşme ve reform çabaları damgasını vurmuştur. Bunun için Batı ülkelerindeki askeri, siyasi ve hukuki sistem yoğun bir şekilde incelenmekte, danışmanlar çağrılmakta, onlara Osmanlı payeleri verilerek ülkelerindeki "gelişmiş" sistemi aktarması beklenmektedir. Hukuk sisteminde doğrudan iktibaslar söz konusudur. Yapılan reformlarda, cephelerde yenilgiler aldıkça artan baskılar önemli rol oynuyordu. Tanzimat, Islahat Fermanları bir bakıma bu baskıların sonucudur.

Aydınlar Avrupa'da gördükleri modellere göre çözüm önerileri getirmeye başlıyordu. Bunlar arasında ilhamını doğrudan pozitivizm ve Fransız ihtilalinden alan Batıcılar olduğu gibi, kendini Batılı olarak gören Türkçüler de vardı. "islamcı” kapsamındaki aydınlar da Dünya tarafından kabul gören meşru bir zemin arayışı içindeydi. Bu arayış yazımızın anahtar kavramını oluşturuyor; Modern dünyanın ortaya çıkardığı fikirlere İslam dininde karşılık bulma çabası. Hilafet ve saltanat

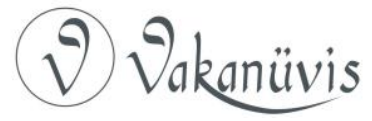


makamının yetkilerinin sınırlandırılması anlamına gelen anayasa ve meşrutiyet sistemine İslam'da zemin aranıyor ve bulunuyordu. Dönemin önde gelen düşünürlerinden Filibeli Ahmet Hilmi bu anlamda temsili bir özellik taşıyordu; Ona göre Meşrutiyet rejimi, Kur'an ve sünnete dayanmaktadır. ${ }^{1}$

“islamcılık" kapsamına giren aydınlar arasında Sait Halim Paşa'nın ayrı ve özel bir yeri vardır. Birçok aydına göre daha özgün, İslam’a daha yakın bir duruş sergilemiştir. Ona göre "her millet kendi düstur ve ananelerine göre terakki eder". Modern Batı'dan alınan medeniyet unsurları yerli ve milli bünyeye uymayabilir. ${ }^{2}$

Düşüncelerini daha sonra ele alacağımı Sait Halim Paşa, Hidiv ailesinde bir Prens olarak 1864'te Kahire'de doğdu. Kavalalı Mehmet Ali Paşa'nın torunudur. Çocuk yaşta ailesiyle İstanbul'a geldi. Yeniköy'deki ünlü yalı onlara tahsis edildi. İstanbul'dan eğitim için İsviçre'ye gitti. Siyaset bilimi okudu, Batı dillerini öğrendi. Dönüşünde Sultan Hamid, nişanlarla taltif ederek ona Şura-yı Devlet azalığı görevi verdi. Rumeli Beylerbeyliği payesine kadar yükseldi.

Ne var ki Avrupa'ya giden bütün Osmanlı aydınları gibi onun da farklı bir gündemi vardı. Yeniköy'deki yalısı Jön Türklerin, muhalif aydınların toplandığı bir yer haline geldi. O zaman aydınlar arasında farklı görüşler olsa da "istibdad" adını verdikleri rejime karşı olmak bir ortak payda durumundaydı. Prens, Sultan Hamid'in son zamanlarında "jurnallendi", Yeniköy'deki yalısına polis baskın düzenleyerek arama yaptı. Kardeşi Abbas Halim Paşa ile birlikte görevden uzaklaştırılarak Mısır’a gönderildi.

Mısır'a, oradan Avrupa'ya geçen kardeşler sürgündeki Osmanlı aydınları, yani İttihatçılarla buluşarak onlara destek oldular. ${ }^{3} \mathrm{Ne}$ de olsa ellerinde büyük bir servet vardı. O sırada Ahmet Rıza, Sami Paşazade Sezai, Mustafa Fazıl Paşa, Abdullah Cevdet, Prens Sabahattin, Abdülhak Şinasi Hisar, hatta Yahya Kemal'in Paris'te olduğu düşünülürse, bu desteğin ne kadar önemli olduğu anlaşılır. Meşrutiyet ilanı ve Sultan

\footnotetext{
${ }^{1}$ Modern Türkiye'de Siyasi Düşünce - İslamcılık, İletişim Yay., İst. 2014, s.64.

2 Said Halim Paşa, Buhranlarımız ve Son Eserleri, Hazırlayan M. Ertuğrul Düzdağ, i̇z Yay. İstanbul 2015, s.67

${ }^{3}$ M. Hanefi Bostan, DiA, c.35, s.557-560.
}

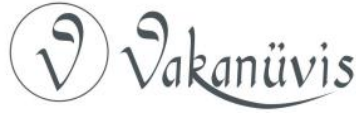


Abdülhamid'in düşürülmesinden önce muhalif aydınların Mısır'daki Hidiv ailesinden destek görmeleri önemlidir. O sırada Mısır İngiliz yönetimindedir.

Sait Halim Paşa birçok aydın gibi Meşrutiyet'in ilanıyla İstanbul'a döndü. Yeniköy Belediye Reisliği, Ayan Meclisi azalığı yaptı. 1909'da onu Selanik'te yapılan İttihat ve Terakki kongresinde görüyoruz. 1912'de Şura-yı Devlet Reisi olarak kabineye girdi. ${ }^{4} \mathrm{Bu}$ arada "Mehmed" imzasıyla Fransızca olarak yazdığı risaleler halinde eserler vermeye başladı.

1913'te Enver ve Talat Beylerin başını çektiği genç subaylar Babıali Baskını düzenledi. Harbiye Nazırı Nazım Paşa öldürüldü. Sadrazam Kamil Paşa zorla istifa ettirildi. Hükümet askeri darbeyle düşürüldü. Bu Almancı kanadın darbesidir diyebiliriz. Avrupa'daki gelişmeler doğrudan Osmanlı'ya yansımaktadır. Mahmut Şevket Paşa Sadrazam oldu. Muhtemelen dengeleri korumak için Sait Halim Paşa, Hariciye Nazırı olarak hükümette yer aldı. ${ }^{5}$

İşte bu sırada İngiltere'den genç bir yazar İstanbul'a geliyordu. Osmanlı Devleti hayranı olan bu gazeteci yazar, İttihat ve Terakki hükümetine büyük umutlar beslemektedir. 1908 inkılabından bu yana ülkede neler değiştiğini görmek, mümkünse Sait Halim Paşa ile görüşmek istemektedir. Bu, Marmaduke W. Pickthall'dır. Şimdi biraz da onu tanıyalım.

\section{Osmanlı Yanlısı Bir İngiliz}

Marmaduke W. Pickthall 1875'te Londra'da muhafazakar bir ailede doğdu. Babası bir rahipti. Kaderin garip bir cilvesi, doğduğu yıl İngiltere, Mısır Hidivinden Süveyş Kanalı hisselerini satın alıyordu. Bu, İngiltere ve Mısır bağlantısının başlangıcıydı. Birkaç yıl sonra 93 harbinin ağır şartları altında İngiltere Mısır ve Kıbrıs'ta yönetimi ele geçirecek, Filistin başta olmak üzere Ortadoğu'ya ağırlığını koyacaktır. Devletin yayılma politikasına paralel olarak birçok İngiliz araştırmacı ve seyyah, Doğu ve Ortadoğu'da gittikleri yerlerde yaptıkları çalışmalarla tanındılar.

\footnotetext{
${ }^{4}$ BOA, I.DUIT.18-79, H.16-02-1331 (1913). (Başbakanlık Osmanlı Arşivi, İrade Dosya Usulü ), Dosya No: 18, Gömlek No: 79, Hicri Tarih.

${ }^{5}$ BOA, I.DUIT 8-80, H-18-02-1331.
}

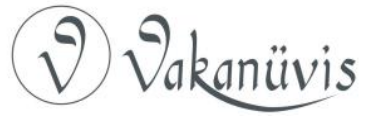


Gertrude Bell ${ }^{6}$, Philby, Harris, Maunsell, Sykes... Masrafları Royal Geographical Society tarafından karşılanarak Hicaz seyahati yapan "Hacı" Burton. Müslüman olarak bizzat görüştüğü Sultan Hamid tarafından "Ingiltere Şeyhülislamı" payesi verilen Liverpool'lu Abdullah Quilliam. ${ }^{7}$

Pickthall'ın hayatını da bu çerçevede düşünmek zorundayız. William Jones gibi bir Doğubilimciyi yetiştiren Harrow School'da eğitim gördü. ilk Ortadoğu gezisine çıktığında daha 19 yaşındadır. Genç bir seyyah olarak iki yıl boyunca Filistin ve çevresinde dolaştı, Arapçayı çok iyi öğrendi. Osmanlı topraklarında hakiki insanlarla karşılaştı, bu toplumu ve inançlarını sevdi. Seyahat ettiği Şam'da Müslümanların samimi ve mütevazı hayat tarzı onu derinden etkiledi. ${ }^{8}$ Dönüşünde İstanbul'a uğradı.

Aslında amacı Ortadoğu ve başta Arapça olmak üzere burada konuşulan dilleri öğrenip İngiliz Dışişlerine girebilmekti. Fakat Mısır Yüksek Komiserliğindeki görev için yapılan seçmeyi T.E. Lawrence kazandı. ${ }^{9}$ Böylece Pickthall'ın hayatının seyri değişmiş oldu. Yine de o bir Ortadoğu aşığıydı. 1907'de ikinci gezisini Mısır'a yaptı ki bu da konumuz açısından önemlidir. Bu defa Mısır'daki İngiliz Yüksek Komiserliği'nin misafiriydi. Bu nedenle orada görevli İngiliz bürokrat, asker ve yazarları yakından gözlemleme imkanı buldu. Aubrey Herbert gibi "serbest" görüşlü olanlarla arkadaşlık kurdu. Fakat George Lloyd, Mark Sykes gibi resmi ve tutucu kanada mensup şahıslarla pek anlaşamadı. Onlar için "istenmeyen adam" oldu.

Evet bu Sykes, Fransız Picot ile Osmanlı devletini paylaşma anlaşmasını yapan İngiliz siyasetçidir. O sırada muhtemel Arap devletlerine bayrak hazırlamakla meşguldür. Hindistan'da itaati, Arap

\footnotetext{
${ }^{6}$ Taha Niyazi Karaca, Sınırları Çizen Kadın Ingiliz Casus Gertrude Bell, Kronik, 2018, 432 s.

7 BOA, HR.SFR 3-549-12, M-06-02-1905 (BOA, Hariciye, Londra Sefareti); Ingiltere Şeyhülislamı Abdullah Quilliam'ın padişahla görüşmek üzere davet edilmesine dair belge.

${ }^{8}$ Kemalettin Yiğiter, William M. Pickthall'un Yakın Doğu ile Ilgili Eserleri ve Türkler, Aktif Yay., İst. 2007, s.55.

${ }^{9}$ N. Khdour - M. Harris - D. Weir, "The Imperial Legacies of T. E. Lawrence: A study in Political and Organizational Hybridity", International Business Research 7 (8), July 2014, s.126.
}

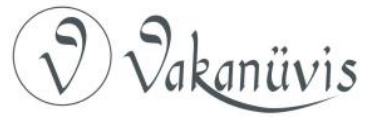


dünyasında isyanı teşvik ediyorlardı. Pickthall genç bir aydın olarak zamanın Mısır Yüksek Komiseri Cromer'e İngilizlerin Osmanlılara yakınlaşması ve ittifak kurması tavsiyesinde bulundu. Bu Hilafete bağlı olan Mısır halkını memnun edecek fakat Hidiv'in otoritesini zayıflatacaktı. Eski bir siyasetçi olan Cromer'in buna cevabı olumluydu. ${ }^{10}$

Fakat İngiliz yönetimi Mısır'da milliyetçiliği körüklüyordu. İngiliz Doğubilimci Blunt bunun teorisi üzerine çalışıyordu. ${ }^{11}$ Kısa bir zaman sonra İngiltere'de Liberaller başa geçtiğinde milliyetçi eğilimler umutlandı. Mısır'ın modernleşme serüveniyle Osmanlı arasında paralellik vardır. İngiltere'de Liberallerin başa geçmesi muhalif Türk aydınlarına yeni bir umut olmuştur. Birinci Meşrutiyeti planladığı düşünülen İngiltere' nin ikincisini de desteklemesi beklenmiştir.

Sahip olduğu derin dil yeteneği ve açık yürekle Mısır ve Suriye'de halkla yakından temas kurma imkanı bulan Pickthall, halkın nabzını tutuyor, yabancıların pozisyonunu görüyordu. Bu dönemdeki yazılarında İslam toplumundaki hoşgörü ortamına vurguda bulunuyordu. Çünkü Batı medyasında Osmanlı topraklarındaki azınlıklar tehlikedeymiş gibi gösteriliyor, esasen müdahale için zemin hazırlanıyordu.

Balkan Savaşları bir dönüm noktası oldu. Batılı güçlerin ve Rusya'nın tam desteğini alan eski Osmanlı teb'ası Balkan ülkeleri, İttihatçıların yönetimindeki Osmanlı topraklarına saldırdı. Yanlış yönetilen Osmanlı Rumeli kuvvetleri yenilgiye uğradı. Yaşanan faciada Balkan Türkleri büyük bir yıkım ve katliam yaşadı. İngiltere dahil Batı medyası tam bir Haçlı ruhuyla Balkan ülkelerine destek verdi. Pickthall işte bu sırada 1912 Kasım ayından itibaren New Age'de Kara Haçlılar adıyla bir dizi yazı yayınladı. Batı medyasındaki önyargılı tutumu eleştirdi. O günkü atmosferde bir Batılı olarak bunu yapabilmek büyük cesaret işiydi. En azından kariyerini gözden çıkarmak anlamına geliyordu. ${ }^{12}$

Bir başka yazısında Osmanlı devletinde hoşgörünün sağlam bir gelenek olduğunu savunuyordu. Orada Hıristiyan ve Müslümanlar eşit

\footnotetext{
10 Pickthall, New Age, 17 Nisan 1919, s.389-391.

${ }^{11}$ Kemal Kahraman, "W. S. Blunt", DiA C.6, İst. 1992, s.246-47.

12 Pickthall, New Age, 7 Kasım 1912, s.8.
}

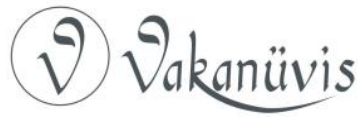


koşullarda yaşıyordu. Dini konularda bile özgürce konuşabiliyorlardı. ${ }^{13}$ Ona göre Türkler 1908 'de yaşanan devrimle bütün İslam Dünyasında Ortaçağ'dan modern çağa adım atan ilk ulus olmuştur. Devrimle birlikte ittihat ve Terakki Partisi başa geçmişti. Ve bu parti için İngiltere'nin desteği çok önemliydi. Esasen geleneksel İngiliz politikalarının gereği de buydu.

Pickthall muhafazakar bir İngiliz olarak yetiştirilmişti ve Müslüman olduktan sonra esasen bu duruşunda değişiklik olmadı. ${ }^{14}$ Türk - İngiliz dostluğu bu düşüncenin önemli bir parçasıydı. Buna dostluk yerine Osmanlı devletinin toprak bütünlüğünden yana olmak da diyebiliriz. Böylece Rusya'nın Güneye inmesi önlenecek ve Hindistan yolu güvende olacaktır. Sebep ne olursa olsun politikada müttefiklik olarak tezahür ediyordu.

Pickthall ölümünden bir süre önce konuyu şöyle özetliyordu;

"Saygı duymak üzere yetiştirildiğim değerler arasında Disraeli'nin dış politikasının önemli bir yeri vardı. Bu politikaya göre ingiltere islam dünyasını yönetecek, yeniden canlanmasına yardımcı olacak ve bunu yaparken Türkiye, tercüman ve aracı fonksiyonu görecekti."15

$\mathrm{Bu}$ politikalar Kırım Harbi'nde zirveye ulaşmış, Osmanlı ve Ingiltere tam bir ittifak içine girmişti. Kırım Harbi sırasında Osmanlı ordusunda Müşavir ve Paşa unvanıyla görev yapan Sir Adolphus Slade burada önemli bir örnek teşkil ediyor. Hatıralarında Osmanlı modernleşmesine ciddi eleştiriler getiriyor. Ona göre bir ulusun ilerleyebilmesi ve yeniden canlanabilmesi için kendi kültürünün esasını teşkil eden kural ve ilkelere bağlı olması şarttır. Bu şekilde atılacak adımlar milletin içgüdülerine ve geleneklerine uygun olacağından halk tarafından daha kolay benimsenecektir. Tabi mevcut dünya şartlarına ve değişen toplumsal ilişkilere uyumlu olması da gerekir. ${ }^{16}$

\footnotetext{
13 The Nineteenth Century and After, December 1912, s.1147.

${ }^{14}$ Tory Muslim, "Conversion of Marmaduke Pickthall, Lawrence M. Stratton", Koinonia XVI (2004), s.78-100.

15 Pickthall, Journal of the Central Asian Society, April 1936, s.221.

${ }^{16}$ Sir Adolphus Slade, Müşavir Paşa'nın Kırım Harbi Anıları, Çev. Candan Badem, Türkiye İş Bankası Yay., İst. 2012, s.17-18.
}

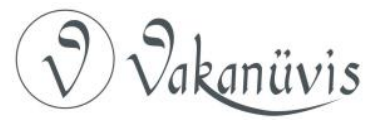


Slade'in görüşleri Sait Halim Paşa ve bizdeki muhafazakar düşünce geleneğine ışık tutar mahiyettedir. Palmerston, Disraeli, Salizbury, Kırım Harbindeki "ittifak ruhuna" sadık politikalar yürüttü. ${ }^{17}$ Bu politikaları desteklemek amacıyla Davit Urquart öncülüğünde İngitere'de Dış İşleri Cemiyetleri (Foreign Affairs Committees) kuruldu. 1876'da bu cemiyetin 21 şubesi vardır. Hidiv Hanedanına mensup Mustafa Fazıl Paşa Sultan Aziz'e Paris'ten bir mektup göndererek meşrutiyet, hatta ilk defa olarak Fransa tipi laik sistemi teklif eden bir mektup yazmıştı. Bu mektup Avrupa gazetelerinde yayınlandı. Davit Urquart kurucusu olduğu Diplomatic Review adlı dergide Mustafa Fazıl Paşa'nın önerisine oldukça sert bir cevap yazmıştır. Ona göre 'Varlığı din ile kaim ve ancak din sayesinde kanun hakimiyeti sağlayan Müslümanların halifesine laiklik teklifinde bulunmak aptalca bir davranıştır'. ${ }^{18}$

Fakat zamanla bu eğilim arka planda kaldı. İngiliz hükümetleri ve politikaları değişti. Sait Halim Paşa Birinci Dünya Savaşı'na doğru ittifak arayışı içindeyken, "Kırım Harbinden bu yana çok şeyin değiştiğini" özellikle vurguluyor. ${ }^{19}$ Bu birden değil belli bir süreçte olmuştur. 93 Harbinden sonra Muhafazakar Disraeli'nin imza koyduğu Berlin Anlaşması'nda Osmanlı topraklarının bütünlüğü korunuyordu. Ne de olsa Ruslar Yeşilköy'e dayanmışken geri çekilmişti. Türkiye'nin de azınlıklar konusunda üzerine düşeni yapması bekleniyordu. 1908 inkılabında İngilizlerin etkisi bilinen bir gerçektir. ${ }^{20}$ Bu sebeplerle Jön Türkler ve İttihat ve Terakki çevrelerinde başlangıçta İngiliz sempatisi had safhadaydı.

Bosna Hersek Avusturya Macaristan İmparatorluğu tarafından ilhak edildi. Bulgaristan bağımsızlığını ilan etti. Fransa Tunus'u, İtalya Trablusgarb'ı işgal etti, nihayet Balkan devletleri Avrupa'daki Türk kentlerini işgal etti. Fakat Batı ülkeleri ciddi bir tepki vermedi. Bu taraflı tutum, Pickthall'ın düşünce ve inanç dünyasını derinden etkiledi. Bütün modern kültür görüntülerine rağmen Ortaçağ'daki Haçlı ruhunun

\footnotetext{
17 Denis Richards - J. W. Hunt, Illustrated History of Modern Britain 1877 - 1964, Longman, London 1977, s.167-173.

18 Davit Urquart, "The Comparison of Christendom with the Ottoman Empire", Diplomatic Review, April 3 - 1867, s.53.

${ }^{19}$ Said Halim Paşa, Buhranlarımız, s.267.

${ }^{20}$ Sina Akşin, Jön Türkler ve Ittihat ve Terakki, Remzi Kitabevi, İstanbul 1987, s.138-139.-
}

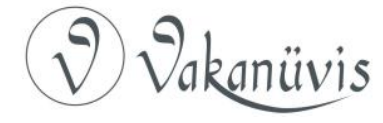


varlığını koruduğunu gördü. Avrupa'nın bu taassubuna karşı yazılarıyla, eserleriyle, konferanslarıyla Osmanlı devletini savunma gayreti içine girdi.

Bir modernleşme adımı olan Meşrutiyet aslında Ingiltere tarafından bir tehdit olarak görülmüştü. Bunun sebebi, esasen Müslümanların gelişmesini istemiyor olmalarıydı. Başarılı bir Meşrutiyet örneği İslam dünyasında İngiliz hakimiyetindeki halklara "kötü" örnek olabilirdi. ${ }^{21} \mathrm{Bu}$ nedenle Osmanlı'nın yeniden toparlanmaması için her şeyi yapmaya hazırdılar. Pickthall bunların farkındaydı ve öyle bir noktaya gelmişti ki Ittihatçıları ve Meşrutiyet hareketini Osmanlı devletinin son umudu olarak görüyordu. Onları yakından tanımak ve mümkünse katkıda bulunmak istiyordu. Elindeki tüm güçleri kullanarak Türkiye'nin parçalanmasını önlemek istiyordu. ${ }^{22}$

\section{Pickthall ve Sait Halim Paşa}

1913 yılında Pickthall ikinci defa olarak İstanbul'a geldiğinde bu duygularının pekiştiğini görüyoruz. Ona göre 1908 'den bu yana beş yıl içinde Türkler oldukça modernleşmiştir. Diktatör adını verdiği Abdülhamid'in casusları yok edilmiş, eşkıyalık ve esaret ortadan kaldırılmıştır. Bayanlar Beyoğlu caddesinde özgürce dolaşabilmektedir. Fanatikler gitmiş onların yerini vatanseverler almıştır. Sistemde Avrupa'daki benzerlerine göre önemli gelişmeler kaydedilmiştir. Her alanda kalkınma ve yenilikler söz konusudur. ${ }^{23}$ Reformcular, fakir Müslümanların kalkınıp "sorumlu ve hür teşebbüs sahibi" vatandaş haline gelmesine yardımcı olacak mahalli idareler kurmuştur. ${ }^{24}$

İttihat Terakki'nin Parti broşüründen alınmışa benzeyen bu izlenimler Pickthall'ın görüştüğü İttihat çevrelerinin ne kadar etkisinde kaldığını gösteriyordu. Bir siyasi grubun sihirli değneğiyle her şey değişmiştir. Kim bilir belki de ülkesindeki bütün o önyargılardan sonra geldiği i̇stanbul'da beklediklerini göremeyince bunun son 5 yılın eseri olduğunu düşünmüştür. Oysa muhalif kanadın başını çeken Ahrarcılar,

\footnotetext{
${ }^{21}$ Erol Ulubelen, Ingiliz Gizli Belgelerinde Türkiye, Aykaç Kitabevi, İst.1967, s. 60-61.

${ }^{22}$ Anne Fremantle, Loyal Enemy, Hutchinson, London 1938, s.224.

${ }^{23}$ M. W. Pickthall, Harpte Türklerle Birlikte, Çev. Kemalettin Yiğiter, Kültür Bak. Yay. Ank. 1990, s.149-150.

24 Pickthall, Harpte Türklerle Birlikte, s.164.
}

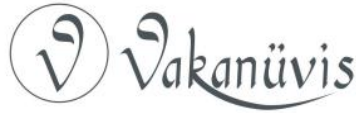


Merkeziyet karşıtlığıyla İngiliz tarzına daha yakın görüşlere sahiptir. Daha sivil, daha özgürlükçü olan bu "liberalleri" Pickthall "kozmopolit" buluyor ve güvenmiyordu. ${ }^{25}$

Balkan Harbi'nin kara bulutları ülkenin üzerinde dolaşıyordu. Bulgarlar Çatalca'ya dayanmıştı. Sait Halim Paşa Hariciye Nazırı olarak Enver ve Talat Paşa ile birlikte yeni iktidara gelen İttihat ve Terakki partisinin üç önemli liderinden birisiydi. İslamcı kanatla Türkçüler arasında gerilim vardı. Sait Halim Paşa "islamcı" ve Osmanlıcı tutumuyla Türkçü kanadın reformları sekülerleştirme çabalarının önünde engel durumundaydı. ${ }^{26}$ Enver Paşa Alman yanlısıydı. Sait Halim Paşa, buraya kadar verdiğimiz ipuçları çerçevesinde bir yandan geleneksel Osmanlı değerlerini savunurken, İngiliz ve Fransızlarla ittifak arayışı içindeydi. Muhtemelen bu sebeple Pickthall tarafından gelen görüşme talebini olumlu karşılamıştı.

Pickthall Sait Halim Paşa ile karşılaştığında karşısında Batı'da siyaset eğitimi görmüş, Arapça ve Farsça'nın yanında İngilizce ve Fransızcayı çok iyi bilen, üstelik aristokrat aileden gelen bir Osmanlı aydını duruyordu. Yabancı elçilerle bizzat diyalog kuran, hatta zamanın İngiliz sefirinin (Sir L. Malet) "dostum" dediği bir devlet adamıydı. ${ }^{27}$ Yazılarının büyük bir kısmını Fransızca yazmayı tercih ediyordu. Öyle ki Mehmet Akif onun makalelerini Fransızca'dan çevirerek Sebilürreşat'ta yayınladı. ${ }^{28}$ Osmanlı'nın Paris sefiri kendi Hariciye Nazırı'na raporlarını Fransızca olarak gönderiyordu. ${ }^{29}$

Dil konusunda Pickthall'ın da özel bir yeteneği vardı. Bir Batılı olarak Batı dillerinin yanında Arapça'ya çok iyi vakıftı. Pickthall, Sait Halim Paşa ile bu anlamda kolay diyalog kurmuş olmalıdır. Arkadaşı Muriel'e yazdığı mektupta Paşa'dan çok etkilendiği anlaşılıyor. O tipik bir Mısırlı değil Hidiv ailesine mensup Kafkas orijinli bir insandır;

\footnotetext{
${ }^{25}$ Yiğiter, William M. Pickthall'un Yakın Doğu ile Ilgili Eserleri, s.48.

${ }^{26}$ Marmaduke Pickthall - Islam and the Modern World, Ed. Geoffrey P. Nash, Brill Leiden/Boston 2017, s.122.

27 Mevlanzade Rıfat, Türkiye Inkılabının İçüzü, Hazırlayan Kemal Kahraman, Kaknüs Yay. İstanbul 2017, s.47.

28 Said Halim Paşa, Buhranlarımız, s.30-31.

${ }^{29}$ BOA, HR.SFR.04.279-58, M.23-10-1913 (Hariciye, Paris Sefareti).
} 
"Bir Alman tarafından çizilmiş Nuh'un gemisi insanları gibi; çok mavi gözler, çok kahverengi yanaklar, çok beyaz renk, çok siyah frak ceket, başının bir parçası gibi görünen çok kırmızı bir fes ve amber bir ağızlıkta sigara ağzının bir kenarında devamlı duruyor. Çok düzgün, uyumlu ve otomatik hareketler, bir oyuncak gibi. Çok sevimli ve Rıfat'ın bana tarif ettiği gibi, büyüleyici bir adam. Dürüst ve terbiyeli, hareketlerinde gösterişli değil mütevazı." ${ }^{30}$

Görüldüğü gibi Pickhtall Paşa'nın görünüşünden oldukça etkilenmişe benziyor. Yazar ve romancı kimliğiyle iyi bir gözlemci olarak tasvire girişiyor. Karşısındaki, bir asilzade, bir devlet adamı olduğu kadar, entelektüel bir insandı. Okuyor ve yazıyordu. Fakat Pickthall bu ziyaretinde henüz onun eserlerini tanımıyordu. Mukallitlerimiz ve Meşrutiyet adlı eserlerini görmemişti. Paşa kendisinden 11 yaş büyüktü. Bu İstanbul ziyaretinde iki kişiden özellikle etkilenmiştir; Birisi kendisine rehberlik eden Türk dostu Misket Hanım. İkincisi Prens Sait Halim Paşa. Bu etkilenme daha sonra eserlerini dikkatle okumasını sağlayacaktır.

Pickthall, Mahmut Şevket Paşa'dan boşalan sadrazamlık makamı için, Parti tarafından önerilen Talat Paşa'ya karşı Prens S. Halim Paşa'yı kuvvetle destekledi. Bunda Osmanlı devletini Almanya kıskacından kurtarma gayreti vardır diyebiliriz. Belgeler İngiltere'nin müttefiki olan Rusya'nın da Sadrazamlığa Sait Paşa'yı "daha uygun" bulduğunu gösteriyor. ${ }^{31} 1908$ - 1913 arasında yaşanan gerilimler ve tartışmalar, Pickthall'ın Erken Saatler adlı romanında canlı bir şekilde ortaya konuyor. ${ }^{32}$ İstanbul ziyareti anılarından ise Harpte Türklerle Birlikte adlı eseri ortaya çıkıyordu. ${ }^{33}$

I. Dünya Savaşı'na girerken malum, Sadrazam Prens Halim Paşadır. Bu bile İtilaf cephesiyle uzlaşma arayışı işareti sayılabilir. O sağduyulu yaklaşımı temsil ediyordu. ${ }^{34}$ Fakat İngiltere belli ki Osmanlıyı gözden çıkarmıştır. Almanya'nın kucağına itmeye kararlıdır. Osmanlı için daha Balkan hezimetinin dumanı tüterken büyük devletlere karşı savaşa girmenin mantığı yoktur. Ne var ki Almancı kanat uygun anı kolluyordu.

\footnotetext{
30 Pickthall, Islam and the Modern World, s.121.

31 BOA, HR. SFR.1, 169-46, M.14-06-1913.

32 M. W. Pickthall, The Early Hours, W. Collins, London 1921, 278 s.

33 Pickthall, With the Turks in Wartime, J.M. Dent, London 1914; Pickthall, Harpte Türklerle Birlikte, Çev. K. Yiğiter, Kültür Bakanlığı, Ank. 1990, 177s.

${ }^{34}$ Ahmet Dağ (Dr.), islam ve Yorum C.III, Malatya Illahiyat Vakfı Yay., Malatya 2017, s.268.
}

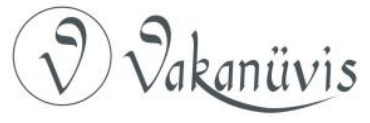


Yeni bir savaşla kaybedilen Balkan topraklarının kurtulacağını ümit ediyordu. Prens ikna olmasa da, bilindiği gibi bir emrivaki uygulanmıştı.

Sait Halim Paşa esasen İngilizlere ve Fransızlara yakınlığıyla tanınmıştır ve bu doğrudan Mısırlı olmasıyla açıklanabilir. Mısır, 30 yıldır Ingiliz hakimiyetindeydi. Ve kendisinin orada önemli boyutta mal varlığı söz konusuydu. ${ }^{35}$ Öte yandan İtilaf devletleri Osmanlı devletine tamamen tarafsız kaldığı takdirde toprak bütünlüğüne kefil olacakları güvencesini vermiştir. Prens savunmasında soruyor; buna ne ölçüde güvenilebilirdi? ${ }^{36}$ Peki Almanya tarafında savaşa girmek daha mı güvenliydi? O zaman daha fazla kazanım mı elde edilmiştir? Bu konuda Prensi anlamak zordur.

Paris Sefiri Rıfat Paşa Sadrazam'a "Almanların siyasi ve askeri durumunun iyi olmadığını, harbe onların yanında katiyen girilmemesi gerektiğini" telgrafla bildiriyordu. ${ }^{37}$ Almancı kanat bu sefiri "eski kafalı ve korkak" olmakla suçluyordu. Prens, kendi ifadeleriyle İtilaf cephesiyle anlaşma yollarını çok aradıktan sonra çaresiz kalarak Almanya tarafına katılmıştır. ${ }^{38}$ Bu süreçte Pickthall Prensle "yolları ayırdı̆̆ını" ifade ediyor. Bunu derin bir görüş ayrılığı olarak değil, belki savaş halinde bir İngiliz vatandaşı olarak meşruiyet zeminini koruma gayreti olarak görebiliriz.

Yine de İngiliz istihbaratı nezdinde "şüpheli" duruma düşmekten kurtulamadı. Londra'da yayınlanan bir gazete "Türklerin her zaman Arapları yok etmek istediğini" iddia eden yazı yayınlamıştı. ${ }^{39} \mathrm{Bu}$ Ermeni iddiaları gibi savaş ortamındaki propaganda faaliyetinin bir parçasıydı. Pickthall gazeteye bir mektup yazarak bunun yalan ve saçma bir haber olduğunu ayrıntılı şekilde anlattı. Gazete bunu da yayınladı. İngiliz istihbaratı hemen harekete geçerek bu mektubun yayınlandığı gazetenin Mısır ve Hindistan'a girişini yasakladı. ${ }^{40}$ Hep Sultan Hamid devri istihbaratından, sansüründen bahsedilir ama aslında kimse İngiliz

\footnotetext{
35 Mevlanzade Rifat, s. 48 - 49.

${ }^{36}$ Said Halim Paşa, Buhranlarımız, s. 273.

37 BOA, HR.SYS. 2392-3, M.09.08.1914.

${ }^{38}$ Said Halim Paşa, Buhranlarımız, s.279.

${ }^{39}$ Saturday Review, Dec.8, 1917.

40 FO.Telegram, No: 1178, Dec.11.1917.
}

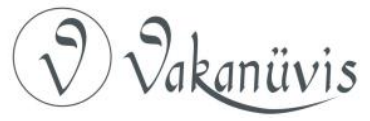


istihbaratının eline su dökemez. ${ }^{41}$ Sultan bunun farkındaydı ve esasen bir karşı-istihbarat sistemi kurmak istedi. Ne var ki son değerlendirmeyi galip olan taraf yapıyordu. Sir Mark Sykes çalışmalarını izlediği ve mektuplaştığı Pickthall'ı "düşman bir devlete karşı dostça yaklaşımı" nedeniyle uyarıyordu. ${ }^{42}$

Savaştan sonra Prens Sait Halim Paşa kötü şartlarda o sırada İngiliz adası olan Malta'ya sürüldü. Ülkesine dönmesine izin verilmeyince Roma'ya yerleşti. Milli Mücadele devam ederken, Anadolu yeni bir oluşum içindeyken o hala zamana uyarlanmış bir İslami sistem arayışı içinde bir şeyler yazıyordu. Bu sırada Pickthall Türkiye'den umutları zayıflamışken yayıncı ve yazar olarak çağrıldığı Hindistan'a gitmiştir (1920). Hayderabad Nizamı́nın çıkarttığı Islamic Culture adlı derginin editörü oldu. ${ }^{43}$ Prens Sait Halim Paşa ile ilgili olarak yaptığı bir açıklamada "bundan sonra onunla konuşacak durumda değilim" diyordu. Yine de Prensi gözden çıkarmadığı anlaşılıyor. Bir yazısında, Ittihat Terakki'nin umutsuz vaka olduğunu fakat bazı üyelerin bu sonucu hak etmediğini açıklıyordu. ${ }^{44}$ Bu sırada Sait Halim Paşa, Roma'da Ermeni bir tetikçi tarafından öldürülmüştür.

TBMM kararıyla Osmanlı saltanatı kaldırıldı̆ında Pickthall Hindistan'da, Hayderabad Nizamı'nın himayesindeydi. Hind Hilafet Hareketi'nin bir üyesi olarak, Hilafet kurumundan ümidini kesmedi. Hatta bunu büyük bir "canlanma ve reform fırsatı" olarak gördü. İslam hilafeti askeri boyuttan ve "belli bir ülkenin siyasi emellerinden" soyutlanmıştır. Şimdi "Dünya Müslümanlarına” ait bir kurumdur. Olması gerektiği gibi İslam'ın standart bir kurumudur. İnsanlığa "gelişmenin" yegane yolunu göstermeye devam etmektedir. ${ }^{45}$

Görüldüğü gibi saltanattan arındırılmış bir hilafet fikri de olumlu karşılanmıştır. Yeter ki TBMM bunu kabul etsin! Bilindiği üzere Hint Hilafet Hareketi artık Hilafet Makamı olan TBMM için kampanya

\footnotetext{
${ }^{41}$ Bkz. Mustafa Çabuk, “İngiliz Belgelerine Göre İngiltere'nin Ortadoğu'daki İstihbarat Merkezi: Arap Bürosu (1916-1920)", Belgi Dergisi, C.2, s.17, Pamukkale Ün.Yay., Kış 2019/1, ss.1130-1147.

${ }^{42}$ Fremantle, Loyal Enemy, s. 276.

${ }^{43}$ Iqtıdar H. Sıddıqui, Islamic Culture, DiA C.23, İst.2001, s.71-72.

${ }^{44}$ The Muslim Standart, Dec.22, 1921.

45 Pickthall, "The True Khilafat", The Islamic Review, XI, II (Nov.1923), s.391.
}

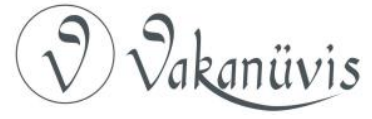


düzenleyerek büyük bir yardım toplamış ve göndermiştir. Hilafetin kaldırılması kararıyla Hint kıtasında büyük bir hayal kırıklığı yaşandı. Hemen üç ay sonra, Mayıs 1924'te Merkez Hilafet Komitesi tarafından Ankara'ya TBMM'ye gönderilmesi düşünülen delegelerin arasında Pickthall'ın adı da vardı. ${ }^{46}$ Yeni Türk Meclisi'ne ulema ve ünlü kişilere Hilafet kararının "tekrar düşünülmesini" isteyeceklerdi. Fakat Ankara'dan izin çıkmadı.

1927'ye gelindiğinde Pickthall hala Türkiye'den ümit kesmiş değildir. Aksine modern Türkiye'yi bir devrim olarak algılamaktadır. Evet bu "milli" bir harekettir ve iyice sınırlanmıştır. Ama yine de Türk devrimi, İslam dünyasının her yerinde işaretleri görülen büyük İslam dirilişinin küçük bir başlangıcıdır. ${ }^{47}$

Pickthall Madras'ta verdiği konferanslarda zaman zaman Sait Halim Paşa'ya atıfta bulunuyordu. Duyduğu yakınlığı, ona olan entelektüel borcunu ifade etmekten geri durmuyordu. Cultural Side of Islam adlı eserinde toplanan bir konferansında Paşa'nın Batı düşüncesine yabancı olmadığını, aynı zamanda Kurân ve Sünneti çok iyi bildiğini ifade ediyordu. Bu nedenle İslam Dünyasına gelecekle ilgili politikalarda tavsiyelerde bulunmak üzere çok iyi donanıma, birikime sahipti. Ve onun İslam dünyasına tavsiyesi, Batılılaşmak değil, i̇slamlaşmaktı. ${ }^{48}$

Pickthall'a göre Sait Halim Paşa'nın islamlaşmak adlı eseri olağanüstü ve çağ açıcı bir çalışmadır. Bu eserde şeriat prensipleri modern insanın anlayacağı şekilde günümüz terimleriyle ifade ediliyordu. Bu, farklı sonuçlara götüren geleneksel alimlerin ve sözde temsilcilerin yaklaşımına hiç benzemiyordu. Türk milleti ve İslam dünyasının içinden geçtiği felaketlere rağmen umut doluydu. ${ }^{49}$

Pickthall, ìslam Şehri adlı eserinde islamlaşmak adlı esere geniş şekilde alıntılarla yer verdi. Prens Sait Halim Paşa'nın fikirlerini Urduca okuyan büyük bir topluma kazandırdı. Sözünü ettiğimiz gibi, Haydarabad Nizmanlığı desteğiyle çıkarılan ıslamic Culture'ın

\footnotetext{
46 Pickthall, Islam and the Modern World, s.115; BOA HR.iM. 112-6 M-02-08-1924.

47 Islamic Culture 101, 1927, s.175.

48 M. Pickthall, Cultural Side of Islam, Ashraf, Lahore 1958, s.130.

${ }^{49}$ Cultural Side of Islam, s. 37, Islamic Culture I, Jan.1927; Yükselişin ve Çöküşün Nedenleri.
}

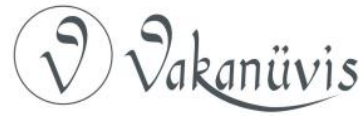


editörüydü. Derginin ilk sayısında Sait Halim Paşa'nın yazıları İslam Toplumunda Reform başlığıyla İngilizce olarak yayınlandı. Daha sonra Urduca'ya çevrilerek Darul Ta'leef wa Tarjuma'da yer aldı.

Bunlar Hint kıtasında Hilafet merkezinden bir mesaj olarak algılanıyordu. Halifenin kendisinden en son Cihat Çağrısı haberi gelmişti o kadar. Bu yüzden Pickthall'ın yayınları ve konuşmaları o kadar etkiliydi ki Prens Sait Halim Paşa Hint Müslümanları arasında bir fenomen oldu. Hint Hilafet Hareketi mensupları için bir rehber, bir rol modeldi. Büyük şair İkbal, Farsça yazdığı ünlü destansı şiiri Cavidname'de Sait Halim Paşa'ya önemli bir yer verdi. ${ }^{50}$

Pickthall 1929'da, hazırladığı Kur'an Tercümesini El Ezher ulemasına inceletmek, görüşlerini almak için Kahire'ye gitti. Bir İngiliz tarafından ilk defa Ingilizceye yapılan tercüme 1930 'da yayınlandı. ${ }^{51} 1935^{\prime}$ de Hayderabad Nizamı'nın himayesindeki işinden emekli olarak Londra'ya döndü. Bir yıl sonra vefat etti.

\section{Sait Halim Paşa ve Pickthall'ın Düşünceleri}

Sait Halim Paşa devlet adamı ve düşünür olarak İslam dünyasında ilgiyle izlense de düşüncelerinin aydın çevrelerde, hatta "islamcı" diyebileceğimiz düşünce geleneğinde yeterince yankı bulduğunu söyleyemeyiz. ${ }^{52}$ Sebepleri ayrıca ele alınabilir. Burada öncelikle "İslamcı" sözcüğünü ihtiyatla karşılamakta fayda vardır. Çünkü hiçbir Müslüman düşünür veya yazar kendini İslamcı olarak tanımlamaz. 0 sadece Müslümandır. Düşünceleri, eserleri olsa olsa "islami”dir. İslamcılık, esasen hariçten bakarak yapılan bir tasniftir. Dikkat edilirse Batı literatüründe İslam'ı referans alarak siyasi, hukuki veya ekonomik alanlara yaklaşanlara 'Islamist'in karşılığı olarak "İslamcı" deme gereği duyuluyor. Yani bir çeşit cüretkarlık olarak görülüyor. Oysa dindar bir yaklaşım içinde yazan Batılı araştırmacılara "Hıristiyancı" diye bir söylem

\footnotetext{
${ }^{50}$ Muhammed İkbal, Cavidname (Çev. Prof. Anna Maria Schimmel), İz Yay. İst. 2010, 439 s.

${ }^{51}$ Kur'an tercümesinin yayınlanma serüveni için bkz. Kemal Kahraman, M. M. Pickthall, Bir Ingilizin Müslüman olarak Portresi, İz yay. İstanbul 1995, s. 195-209.

52 Michelangelo Guida, "The Life and Political İdeas of Grand Vezir Said Halim Pasha", Turkish Journal of Islamic Studies, 18 (2007), s.103.
}

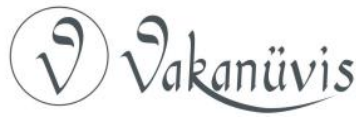


söz konusu değildir. Sait Halim Paşa düşünceleri ve duruşuyla, tam da bu alana girmiş oluyor.

Düşüncelerinin ülkesinde yeterince yankı bulmaması Sait Halim Paşa'yı Pickthall'a daha da yaklaştırıyor. Çünkü Pickthall da kendi toplumunda pek popüler değilken Hindistan'da meşhur olmuştu. Pickthall, Prens Sait Halim Paşa dışında Osmanlı aydın geleneğini pek bilmiyordu. Namık Kemal ve Recaizade Ekrem'in “vatanperver bir şevkle şiirler yazdığından" 53 bahsediyor ama bu Genç Türklere duyduğu genel sempatiyle ilgilidir. Sadullah Paşa, Şinasi, Ahmet Rıza gibi radikal pozitivist aydınları tanımamasını anlayabiliriz. Fakat İslamcı kapsamına alınan düşünür ve yazarları tanıdığına, okuduğuna dair de fazla bir işaret yoktur. Bunu belki Türkçeyi pek bilmemesine bağlayabiliriz.

İttihat ve Terakki'yi destekleyen "İslamcı" aydınların yoğun bir şekilde modern düşünce ve kurumlar üzerine çözüm ve uzlaşma arayışı içinde olduğunu görüyoruz. Bu açıdan modern eğitim almış "İslamcı" aydınlarla geleneksel eğitim almış olanlar arasında sanıldığı kadar büyük bir yaklaşım farkı yoktur. ${ }^{54}$ Hilafet merkezinden umut zayıflamıştır. İslamcı sayılanlar dâhil aydınların büyük çoğunluğu Abdülhamid devrine "istibdad" adını veriyordu. Pickthall bunu "diktatörlük" olarak çeviriyordu. ${ }^{55}$ Prens de Pickthall da eserlerinde böyle kullanıyordu. Oysa Hindistan olsun Arap alemi olsun bütün İslam dünyasında Sultan Hamid Halife olarak büyük saygı duyulan bir şahsiyetti. Ülke hangisi olursa olsun, Müslüman halk tarafından büyük ölçüde seviliyordu. Bu sevgiyi günümüzde bile izlemek mümkündür.

Konumuza dönersek, Müslüman aydınlar arasında Terakki adı altında pozitivizmin yaydığı düşüncelerle İslam'ı telif etme gayretleri baskın durumdaydı. İttihat ve Terakki iktidarında Batıcılık, Türkçülük, İslamcılık gibi tasnifler öne çıkmaya başlamıştı. Balkan savaşları, Arap dünyasında palazlanan milliyetçi akımlar İstanbul'da Türkçülük akımını destekleyen gelişmeler olmuştu. Fransız ihtilalinin yaydığı fikirlerden birisinin de ulusçuluk olduğu unutulmamalıdır. Bu fikir Batı Avrupa'da ulusal

\footnotetext{
${ }^{53}$ Kahraman, M. M. Pickthall, s. 229.

54 İsmail Kara (Hazırlayan), Türkiye'de islamcılık Düşüncesi I, Risale Yay., İst.1994, s.22.

55 Pickthall, Harpte Türklerle Birlikte, s.149.
}

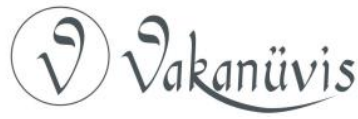


birliklere yol açarken Doğu Avrupa'daki imparatorluklarda çözülmeye zemin hazırlıyordu.

Osmanlı entelektüel dünyasında, cephedeki yenilgiler karşısında Batıdan gelen düşünce akımlarının ağırlığı vardır. Herkes bilim ve teknikte geri kalındığını ister istemez kabul ediyordu. Bunun sebepleri araştırılırken çözüm önerilerinde ayrışmalar söz konusudur. Sihirli sözcükler bellidir; İttihat ve Terakki. Buradaki ittihat, Osmanlı milletlerinin birliğidir. Batı dünyasındaki askeri ve teknik gelişmelerle yaldızlanan "terakki", Osmanlı dünyasında da anahtar kelime olmuştu. Karalardaki ve denizlerdeki gücüyle kendini ispatlamış durumdaydı. Bu nedenle kimse ona karşı duramıyordu. Müslüman düşünürlerin ortak sloganı belliydi; İslam terakkiye mani değildir. Bu daha çok baskı altında verilmiş ifadelere benziyordu. Ne var ki Pickthall da aynı slogana bağlıydı. ${ }^{56}$ Osmanlı toplumunda gelişme yanlısı anlamında "prograsive" aydınları destekliyordu. Bunlar İttihatçılardan başkası değildi.

İşte bu ortamda Sait Halim Paşa adeta aşağı̆ık kompleksinden kurtulmaya davet eder gibi gür bir seda ile düşüncelerini açıkladı. Bizi Batı tahakkümünden kurtaracak olan şeyin şahsiyet olduğunu vurguladı. ${ }^{57}$ Pickthall, Sait Halim Paşa ile görüştüğünde henüz Müslümanlığını ilan etmiş değildi. Fakat bir etkilenme sürecindeydi. Aile geleneğinden Osmanlı politikalarını, Hint Hilafet hareketinden -bu da Imparatorluk bağlarıyla ilgilidir - İslam anlayışını, Prens Sait Halim Paşa'dan ise İslami kurumlar ve Batı ilişkileriyle ilgili fikirlerini almıştı. Prensin sağlam, akılcı ve inançlı üslubu onu fazlasıyla ikna etmişti.

Sait Halim Paşa ile Pickthall’ın düşüncelerine baktığımızda İslam ve modern dünya arasındaki sorunlar ve kavramlar üzerine önemli benzerlikler söz konusudur. Her ikisi, dinin modern zamanla bir problemi olmadığını, Müslümanların onu yanlış veya eksik yorumladığını vurguluyordu. Sait Halim Paşa İslamcı bir düşünür olarak kabul edilse de modern kültürle barışık bir muhtevaya sahiptir. Ona göre zamanın yaygın düşünceleri olan İdealizm ve Pozitivizm zaten İslam'ın içinde mevcuttur. ${ }^{58}$ Batı Medeniyetinin üstünlük sebebi "ilim zihniyeti”

\footnotetext{
${ }^{56}$ Said Halim Paşa, Buhranlarımı, s.150; Pickthall, Harpte Türklerle Birlikte, s.161.

57 Said Halim Paşa, Buhranlarımız, s.153.

58 Said Halim Paşa, Buhranlarımız, s.185.
}

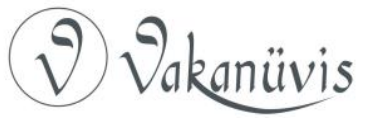


ile "tecrübe usulü"dür. Ona göre "Tecrübe ve fenne" dayanan bilgimiz arttıkça Esmaül Hüsna'nın manası daha iyi anlaşılacaktır. ${ }^{59}$

Bu yaklaşım, sistemle ilgili Anayasa ve meşrutiyet tartışmalarında da kendini gösteriyordu. Ona göre devlet başkanını oylarıyla seçmek milletin hem hakkı hem vazifesidir. ${ }^{60}$ islamcı geleneğe bağlı yazar ve düşünürler de taleplerinin "milli iradeye" uygun olduğunu belirtme gereği duydular. ${ }^{61}$ Bunları mevcut dünya konjonktüründe meşru bir zemin arayışı olarak değerlendirebiliriz.

Paşa, Fransız tarzı ihtilale karşıdır fakat onun getirdiği hürriyet, eşitlik, adalet, temsil, anayasa, kuvvetler ayrılığı gibi kavramların zaten din ve kültürümüzde mevcut olduğunu söyler. Ne var ki bizde farklı muhtevalara sahiptir. Batı ülkelerindeki meclislerde yaşanan kargaşayı cazip bulmaz. Ona göre siyasi partiler, gruplar arasında husumete yol açmaktadır. Bizde esas olan rekabet değil dayanışma ve yardımlaşmadır. Bu yaklaşımıyla Şeyhülislam Mustafa Sabri Efendi ile aynı fikirdedir. ${ }^{62}$ Aslına bakarsanız istibdadından şikayet ettiği Sultan Hamid'le de aynı fikirdedir. Bilindiği gibi Sultan da "siyasi kargaşaya" son vermek için Meclisi tatil etmiştir.

Sait Halim Paşa o sıra çok moda olan "milli hakimiyet" kavramına karşı çıkıyordu. Fakat bu demokrasiye karşı çıkma anlamında değildi. ${ }^{63}$ Ona göre Müslüman aydınlar Batı ülkelerinde görülen ve gözleri kamaştıran refahın, "milli iradenin hakimiyeti" prensibinin mücizevi sonucu olduğunu sanıyordu. Oysa milli irade kavramı suni olarak ortaya atılan bir şeydir, aslında çoğunluğu temsil etmemektedir. ${ }^{64}$ Batı demokrasisi Batı toplumlarının ve kültürünün eseridir. Burada Paşa üzerinde düşünmeye değer bir görüş ortaya atıyor. Ona göre Osmanlı toplumu kuruluş devrinden beri zaten hakiki bir demokrasi usulüyle yaşamıştır. ${ }^{65}$ Öte yandan, İslam cemiyetinde milli meclis, milletin

\footnotetext{
59 Said Halim Paşa, Buhranlarımız, s.187.

60 Said Halim Paşa, Buhranlarımız, s.255.

${ }^{61}$ Modern Türkiye'de Siyasi Düşünce, 131.

${ }^{62}$ Mustafa Sabri Efendi, Hilafetin Ilgasının Arka Planı, İnsan Yay., İstanbul 2013, 62.

${ }^{63}$ M. Hanefi Bostan, "Sait Halim Paşa ve Fikirleri", 21.Yüzyılda Eğitim ve Toplum 8/22, 2019, s.53-90.

64 Said Halim Paşa, Buhranlarımız, s.227.

${ }^{65}$ Said Halim Paşa, Buhranlarımız, s.88.
}

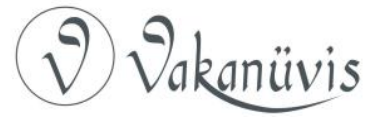


seçkinlerinden meydana gelecektir. Meclis-i Mebusan ve erken Cumhuriyet devri meclislerinin memleketin seçkinlerinden oluştuğu düşünülürse pek de haksız sayılmaz. Mebuslar iktidar tarafından merkez veya taşradaki elitler arasından seçilmiştir.

Osmanlı'nın son dönemi ve erken Cumhuriyet devrinde İslamcı geleneğe yakın duranlar, Fransız tipi laikliği ve jakobenliği eleştirirken, itiraf etseler de etmeseler de kendilerini Anglosakson muhafazakarlığı modeline yakın buldular. O sırada Anglosakson kültürün üstünlüğüne dair -üstelik bir Fransız yazar tarafından- kitap bile yazılmıştır. ${ }^{66} \mathrm{Bu}$ yaklaşımın Fransız tipi ceberut modernizme karşı bir argüman sağladığı gerçektir. Bizim için önemli yanı da işte burasıdır; İslamcı gelenek, Sait Halim Paşa ve Pickthall arasında ortak bir payda oluşturmasıdır.

Öte yandan Prens Sait Halim Paşa, İslami kurumların "kemâl" halinde olduğunu vurgular. Ona göre insanın ihtiyaçları değişir ama tabiatı asla değişmez. İslam'ın ortaya koyduğu düstur ve kurallar insan tabiatına tamamen uygundur ve kıyamete kadar geçerlidir. ${ }^{67}$ i̇slam'ın getirdiği hukuk, insanlığı pek gururlu ve iddialı olan 'akılcılık' görüşünün "vehimlerinden ve yanlış nazariyelerinden" kurtarmıştır. İslam din olarak en geniş anlamda bir insanlık hukuku ve yoludur. ${ }^{68}$. Sonuç olarak "Batıda her yol Roma'ya bizde ise Mekke'ye çıkar".69

Bu ifadeler modern eğitimden geçmiş ve en üst düzeyde görevler üstlenmiş olan Paşa için cesurca kabul edilmelidir ve ihtimal kendisini "İslamcı" düşünür kapsamına aldırmaktadır. Son dönem Şeyhülislamı Mustafa Sabri Efendi ile aynı şeyleri söylediği bir gerçektir. Sabri Efendi de şöyle diyor; "İslam hukuku her zaman ve mekanda, tüm fert ve devletlerin ihtiyaçlarını karşılayacak düzeydedir". ${ }^{70}$

Pickthall ilhamını bu yaklaşımdan alarak katkıda bulunuyor; Ona göre İslam kanunu statik değil dinamiktir. Katı değil fakat her çağın ve

${ }^{66}$ Edmond Demolins, À quoi tient la supériorité des Anglo-Saxons?, Didot, Paris 1897; Anglo - Saxon Superiority: To What It Is Due?, The Leadenhall, London 1899; Anglosaksonların Esbab-ı Faikiyeti Nedir?, Araks Matbaası, İst.1914. Le Play ekolü öğrencisi ve Prens Sabahattin'i etkileyen Fransız düşünür.

67 Said Halim Paşa, Buhranlarımız, s.179.

${ }^{68}$ Said Halim Paşa, Buhranlarımız, s.170.

${ }^{69}$ Said Halim Paşa, Buhranlarımız, s.218.

70 Mustafa Sabri Efendi, Hilafetin Ilgasının Arka Planı, s.29.

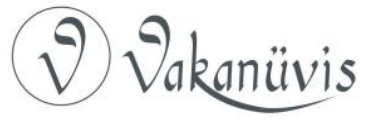


toplumun ihtiyaçlarına cevap verebilecek kadar esnektir. ${ }^{71}$ Akılcılık konusuna gelince Türkler Hanefi ekolüne bağlıdır. Bu ekol, İslam'da insan aklını hukuki bir rehber ve ölçü olarak kabul eden tek Sünni mezhebidir. ${ }^{72}$ Hindistan'da da Müslümanların çoğu bu ekole mensuptur.

Sait Halim Paşa, taklitçiliğe karşıdır. Ona göre her ülkenin idari sistemi ve kurumları kendi kültürüne ve ihtiyacına göre oluşur. Başka ülkelerin tecrübelerinden "zahmetsizce istifade etmek" belki çekicidir fakat hüsranla sonuçlanabilir. ${ }^{73}$ Prens, Batı hayranlığına karşı çıkıyor ve bunu "ruhların vatan değiştirmesi" olarak tanımlıyor. Kurtarıcı formül "Avrupa medeniyetini millileştirmektir". ${ }^{74}$ Yani içselleştirmektir. Bunun yolu, Batı medeniyetinin üstünlüğünün sebebi olan “ilim zihniyeti ile tecrübe usulünü" birleştirerek hakikatleri ortaya koymaktır. Öte yandan, ahlak, fazilet ve terbiye, ilim ve bilgiden daha üstün tutulması gereken olgulardır. ${ }^{75}$

Sait Halim Paşa'ya göre ilmin, dinin vatanı olmaz, beynelmileldir. Uygulamaya dayanan modern bilimlerdeki gelişmeler, madde ve enerji arasındaki kusursuz ahenkle ilgili yeni bilgiler, Tanrı'nın varlığını daha kuvvetli bir şekilde ıspatlayacaktır. ${ }^{76}$ Bu görüşlere baktığımızda mesela Said-i Nursi'yi oldukça etkilediğini veya aynı yaklaşımı paylaştığını söylemek mümkündür. Fakat burada maddi ve manevi ilimler arasındaki uyum önemlidir. Prens'e göre, Ahlak seviyesi fen ve sanayideki seviyeyi bulduğu zaman medeniyet kemalini, dengesini bulmuş olur. İşte o zaman Müslüman aydınlar İnsanlığın "medeniyet yolundaki ortak hareketine" katılacaktır. ${ }^{77}$

Sait Halim Paşa, Pickthall'a ışık tutacak şekilde modern kurumlar ve kavramlarla ilgili görüşlerini bir bir ortaya koyuyordu. ${ }^{78}$ Ona göre en iyi Müslüman en iyi insandır. Kadın erkek bizde hukuken eşittir. Feminizm ise bir sapmadır. Toplum buna karşı çıkıyorsa, meşru müdafaa hakkını

\footnotetext{
${ }^{71}$ Islamic Review VII, Dec.1919, s.441.

72 Pickthall, Harpte Türklerle Birlikte, s.163.

73 Said Halim Paşa, Buhranlarımız, s. 77.

74 Said Halim Paşa, Buhranlarımız, s.104.

75 Said Halim Paşa, Buhranlarımız, s.137

${ }^{76}$ Said Halim Paşa, Buhranlarımız, s.187.

77 Said Halim Paşa, Buhranlarımız, s.264.

78 Guida, "Said Halim Paşa", s.101-118.
}

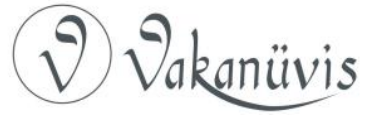


kullanmaktadır. ${ }^{79}$ Bu noktada Pickthall'ın farklı bir yaklaşımda olduğunu görüyoruz. O sırada Batı ülkelerinde kadınların eşit haklara sahip olması için tartışmalar ve eylemler yapılmaktaydı. Henüz İngiltere'de seçme ve seçilme hakkına sahip değildirler. Hindistan'da ise kadınların sosyal statüsü pek iç açıcı değildi. Pickthall bu ortamda yazılarında İslam'da kadın haklarının çok ileri düzeyde olduğunu vurguluyordu. Dahası, İslam peygamberinin gerçek anlamda bir "Feminist" olduğunu savunuyordu. ${ }^{80}$

Aristokratik meziyetler / faziletler Prens Halim Paşa'nın çokça başvurduğu bir kavramdır. Seçkinleri sağlıklı toplumun vazgeçilmez unsuru olarak görüyordu. Pickthall'a göre İslam hukuku bir yandan insan kardeşliğini, aristokratik meziyetleri ve demokratik özgürlüğü topluma yerleştirirken öte yandan aynı şeylerin kötülüklerinden koruyordu. Islam Şehri adlı eserinde Sait Halim Paşa'nın görüşlerini ayrıntılı olarak özetledikten sonra bütün bu ilkelerin ileri bir yönetim programı olarak bugünkü dünyada herhangi bir modern devlette görülemeyeceğini ifade ediyordu. ${ }^{81}$

Pickthall, İngiliz üst sınıf bağlantılarına sahip bir birey olarak modern dünyaya atılmıştı. Victoria çağı kolonici dönem kültürünü almış İngiliz bir aydındı. Modern ve reformcu bir Müslüman olarak Prens Sait Halim Paşa'nın seçkinci görüşlerini benimsemişti. Paşa'ya göre İslam cemiyeti aynı zamanda hem demokratik hem aristokratikti. ${ }^{82}$ Bu arada Türklere bir özellik tanımaktaydı. Ona göre Türkler, Müslümanlığı kabul eden milletler arasında İslam'ın esaslarını en iyi anlayan ve en güzel şekilde tatbik eden milletti. ${ }^{83}$ Pickthall, Sait Halim Paşa ile aynı fikirdeydi;

Türk Milleti bütünüyle aristokrat hatta bütün islam dünyasının aristokratları olarak kabul edilebilirler. Böyle olduğu için de samimi olarak doğunun refahını ve barış içinde olmasını isteyen her devletin tam anlamılla desteğine layıktırlar. ${ }^{84}$

\footnotetext{
79 Said Halim Paşa, Buhranlarımız, s.133.

80 Pickthall, Islam and Progress, The Islamic Book Society, Lahore 1920, s.13.

81 Pickthall, İslam Şehri, İslam Medeniyetinin Dinamikleri, Çev. Yusuf Kaplan, Külliyat Yay. İst.2018, s.196.

82 Said Halim Paşa, Buhranlarımız, s.172.

83 Said Halim Paşa, Buhranlarımız, s.199.

84 Pickthall, Harpte Türklerle Birlikte, s. 133.
}

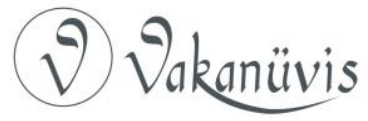


Pickthall Sait Halim Paşa'nın görüşlerini büyük ölçüde benimsedi ve yazılarında onlardan ilham aldı. Londra'da Islam ve Modernizm adlı konferansını verdikten sonra Müslümanlığını ilan etti (1917). ${ }^{85}$ içinden çıktığı toplum Güneş Batmayan İmparatorluk da olsa sosyal sınıflar arasında derin uçurumlar bulunan, aşırı zengin ve yoksulların yaşadığı bir tezatlar ülkesiydi. Kıyasıya rekabet, kast sistemi, sınıf mücadelesi, sömürü, sonuç olarak mutluluktan uzak insanlar. Pickthall bu ortamdan Ortadoğu'ya Osmanlı topraklarına gittiğinde burada sınıf farkları ve kıyasıya rekabet olmayan, mütevazı, mutlu insanlarla karşılaştı. Kendisi de rekabeti sevmeyen bir insandı. ${ }^{86}$ Ona göre Batı uygarlı̆ı̆ının doğurduğu gruplar, ülkeler ve dinler arasındaki çatışmaları İslam'ın geleneksel kurumlarıyla yumuşatmak, uzlaşma zemini oluşturmak mümkündür. ${ }^{87}$

Pickthall, Müslüman toplumların Batı uygarlığını birebir taklit etmeye çalışmalarının bir çeşit intihar olacağını ifade ederek uyarıda bulunuyor. Böyle bir durum, onların Batı kültüründe maddi ve manevi anlamda kötü olarak gördükleri her şeyi kabul ettikleri anlamına gelecektir. Bu durumda kendi medeniyet birikimleri bundan böyle insanlık için "hayır ve huzurun" kaynağı olma iddiasını kaybedecektir. Sorgusuz bir şekilde teslim olmak, İslam'ın getirdiği değerleri kaybetme tehlikesine yol açar. Ne var ki Batı uygarlığı ile bütünüyle ilişkileri koparmak da bir çeşit intihar anlamına gelecektir. Çünkü bu uygarlık, günümüzde geçerli olan bilgi ve bilimleri, teknoloji ve verimli üretim sistemlerini içinde taşımaktadır. Onlarla teması kaybederek, sadece geçmişten gelen birikimle bugün varlığı etkin bir şekilde sürdürmek mümkün değildir. Pickthall burada dengeli bir yaklaşım önerisinde bulunuyor. ${ }^{88}$

Bunlar Sait Halim Paşa'nın da dile getirdiği düşüncelerdir. ${ }^{89}$ Pickthall, "özgürleştirici ve aydınlatıcı" prensiplere sahip olan İslam dinini sınırlı bir alana hapseden, dar görüşlü ulamadan hoşlanmama noktasında da Paşa'nın görüşlerini paylaşıyor. ${ }^{90}$ Ona göre İslam hukuku yeniden elden

\footnotetext{
85 Pickthall, Islam and the Modern World, s.57.

86 Yiğiter, William M. Pickthall'un Yakın Doğu ile ilgili Eserleri, s.52.

87 Pickthall, İslam Medeniyetinin Dinamikleri, s.194.

88 Pickthall, islam Medeniyetinin Dinamikleri, s.146.

89 Said Halim Paşa, Buhranlarımız, s.262.

90 Pickthall, Islam and the Modern World, s.124, Buhranlarımı, s.119,196.
}

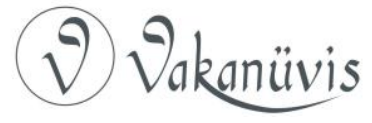


geçirilmelidir. Çağımızın sorunlarına, toplumlarına uygun, geçerli, kalıcı çözümler üretmek üzere araştırmalar yapılmalıdır. Bu noktada bankacılık sisteminden örnek veriyordu. Günümüz ekonomik ilişkilerinde banka kurumunun vazgeçilmez bir rol oynadığından yola çıkarak, bize uygun, faize değil yardımlaşmaya dayanan bir sistem bulunmalı diyordu. Aynı şekilde sömürüye dayanan, kuvvetlinin zayıfı ezdiği mevcut kapitalist sistem yerine insanlık hukukuna ve adalete dayanan bir ekonomik sistem kurulmalıydı. Kötü olanı reddetmek yetmezdi, Müslümanlar onun yerine bir şey koymak zorundaydı. ${ }^{91}$

Pickthall'a göre Müslüman toplumlar modern çağın iyi ve kötü yanlarını birbirinden ayırt ederek, iyi yanlarından faydalanmalıdır. Kötü gördüğü şeylerde ise onların yerine daha uygun ne varsa bulup yerleştirmelidir. Bunu yapmakla yükümlüdür. Modern dünyanın olumsuz yönleri varsa bunu giderecek ve yol gösterecek olanlar, Müslümanlardır. Batı dünyasında kurtuluş için ortaya çıkan nice düşünürler, buluşlar, reçeteler insanlığa mutluluk getirmemiştir.

Pickthall geleneksel "cihat" kavramına alışılmışın dışında bir anlam yüklüyordu. Bu da o dönem yaşanan siyasi dönüşümün ilk sonuçları arasında sayılabilir. Kavramı dini anlamından soyutluyordu. Ona göre bir toplulukla sırf inançları yüzünden savaşılmaz. Ceht kavramından gelen cihat, dünyada gördüğümüz yanlışlara karşı iyi şeyler için mücadele etme halidir. Esasen bir medeniyet olarak İslam tarih boyunca hep bunu yapmıştır. Hedef ümmete dayanan siyasi bir otorite kurmak değil Allah'ın adını yüceltmek, O'nun hükümlerine dayanan bir sistem ortaya koymaktır. Her çağın kendine göre bir cihadı vardır. Bu günümüzde gerekli bilgi ve donanıma sahip olmaktır yani çağımıza uygun, iyi bir eğitim almaktır. ${ }^{92}$

Bu noktada Pickthall'ın Hindistan'da Gandi'nin başlattığı pasif direniş hareketine destek verdiği hatırlanmalıdır. Mustafa Sabri Efendi konuya değinirken ilginç bir yaklaşımda bulunuyor ve diyor ki, Hint Hilafet Hareketi İngilizlere karşı bağımsızlık mücadelesi vermeye çalışırken, Bağlantısızlar Hareketine, yani Gandi'nin sivil itaatsizlik yöntemine

\footnotetext{
91 Pickthall, İslam Medeniyetinin Dinamikleri, s.146.

92 Pickthall, İslam Medeniyetinin Dinamikleri, s.147.
}

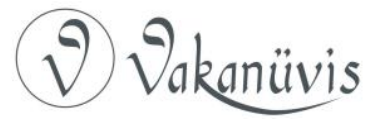


doğru sürüklenerek pasifize edilmiştir. ${ }^{93}$ İngilizlerin istediği zamanda ve zeminde bir anlaşma sağlanmıştır. Bu da günümüze kadar gelen sorunlara yol açmıştır.

Pickthall, İslam Şehri adlı eserinde İslam toplumunda hukukun önemini özellikle vurguluyor. Orada hukuk, herkesin kabul etmek zorunda olduğu bir otoritedir. ${ }^{94}$ Modern çağda ortaya çıkan milliyetçilik akımlarını "yerel savunma refleksi" olarak görüyor. Buna karşı evrensel İslam kardeşliğini savunuyor. Avrupa uygarlığı Hıristiyan olmayan herkesi yok etmeyi düşünürken İslam medeniyeti tarih boyunca tam bir hoşgörüyle davranmıştır. Farklı din ve kültürler i̇slam hukukunun koruması altındadır. Mesela Çanakkale savaşlarında Almanlar zehirli gaz kullanmayı önerdiğinde Osmanlı bunu reddetmiştir. Bu İslam hukukunun evrensel değerlere verdiği önemle ilgilidir. Burada Pickthall'ın "evrensel değerler", hatta "evrensel insan kardeşliği" kavramını kullanması bize Sait Halim Paşa'nın "Insanlığın medeniyet yolundaki ortak hareketi" ifadesini hatırlatıyor ki bunlar Müslüman düşünürler için sıradışı ifadelerdir. ${ }^{95}$

Pickthall, Hindistan'da gördüğü sosyal hayata sıkı eleştiriler getirmekten kaçınmıyor. Geleneklerin kıskacındaki Müslümanlar Modern dünyada neyin doğru neyin yanlış olduğunu karıştırmış durumdadır. Birçok kurum birer isimden ibarettir. Bu ortamda kurumların ne ölçüde i̇slami olduğundan kuşkuludur. Toplumun modern bilime ulaşması, ondan korkmaması gerektiğini vurguluyor. Özellikle kadınların eğitim görmemesine karşı çıkıyor. Müslüman kadın ve erkeklerin bütün "Işıklara" ve bilgilere sahip olmasını sağlamakla yükümlüyüz, diyor. Pratik ve maddi bilgilere "seküler" damgasını vurup olumsuz bakmamalıyız. Pickthall'a göre çağdaş bilimler, İslam medeniyetinin o muazzam günlerinde geliştirdiği bilimsel birikimin devamından ibarettir. İslam'ın getirdiği temel ilkelere ters değildir. Zaten o birikimin içinde mevcut olan şeylerdir. Ve şöyle bir sonuca varıyor; "islam bilim, sanat ve edebiyatının dirilişi, insanların zihinlerinin özgürleşmesiyle gerçekleşecektir". ${ }^{96}$

\footnotetext{
93 Mustafa Sabri Efendi, Hilafetin Ilgasının Arka Planı, s.205.

${ }^{94}$ Pickthall, islam Medeniyetinin Dinamikleri, s.192.

95 Pickthall, İslam Medeniyetinin Dinamikleri, s.194.

96 Pickthall, İslam Medeniyetinin Dinamikleri, s.198.
}

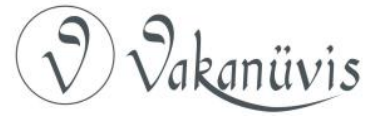


Bu noktada Sait Halim Paşa'yı hatırlamakta fayda var. Paşa'ya göre bugün "ilim ve fenler" Batı ülkelerindedir. Toplum olarak yapmamı gereken şey açıktır; onları Batı ülkelerinden öğrenmek. Fakat bunu yaparken dikkat etmemiz gereken şey, sadece "maddi ilimleri" almaktır. Manevi dünyada, hukukta, sosyal alanlarda onlardan öğreneceğimiz bir şey yoktur. ${ }^{97}$

Dönemin "İslamcı" şairi Mehmet Akif, Sait Halim Paşa'dan tercüme ettiği eserin giriş kısmında ondan "İslam ümmetinin en önemli mütefekkirlerinden şehid-i mağfur" diye bahsediyor. ${ }^{98}$ Sait Halim Paşa ve Pickthall'ın düşüncelerini mısralarında özetliyor;

Sırr-ı terakkinizi siz,

Başka yerlerde taharriye (aramaya) heveslenmeyiniz.

Onu kendinde bulur yükselecek bir millet;

Çünkü her noktada taklid ile sökmez hareket.

Alınız ilmini Garb'ın, alınız sanatını;

Veriniz hem de mesainize son süratini.

Çünkü kabil değil artık yaşamak bunlarsız;

Çünkü milliyeti yok sanatın, ilmin, yalnız...99

\section{Sonuç}

Prens Sait Halim Paşa Batılı eğitim görmüş, Fransız ve İngiliz kültür ortamlarında yetişmiş Mısır hanedanına mensup bir Osmanlı devlet adamıdır. "İslamcı" geleneğe rehber olmuş önemli eserlerin sahibi bir düşünür ve yazardır. Döneminde ve kendisinden sonra gelen İslami hassasiyete sahip aydın ve düşünürleri ya etkilemiş, ya da onların birçok görüşünü, yaklaşımını, paylaşmıştır. Bu, Dünyayı etkileyen Batı

\footnotetext{
97 Pickthall, İslam Medeniyetinin Dinamikleri, s.239.

98 Sebilürreşad, c.19, no:493, 26 Şubat 1338 (1922).

${ }_{99}^{9}$ Mehmet Akif Ersoy, Safahat, Hazırlayan Vahap Akbaş, İstanbul 2007, s.376.
}

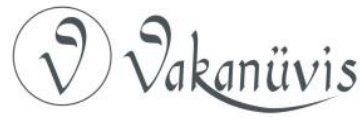


kültürüne karşı özgün bir duruş sergileme, yerli inanç ve kültür temellerinde karşılık bulma çabasıdır.

Aynı dönemde yaşayan İngiliz yazar, düşünür ve romancı Marmaduke W. Pickthall, bizzat görüşme imkanı bulduğu Sait Halim Paşa'nın fikirlerinden etkilenmiş, onların Ortadoğu ve Hind kıtasında tanınmasını sağlamıştır. Kendisi Osmanlı devletinin toprak bütünlüğünün korunmasından yana olan geleneksel İngiliz muhafazakar politikalarına bağlıdır. Esasen eğitim ve çevre olarak benzer bir arka plana sahip olan bu iki aydın arasındaki etkileşim o dönemde aydınların düşünce ve yaklaşım sorunlarını da ortaya koyar mahiyettedir. Eserleri ve yaklaşımları, modernizmin ortaya çıkardığı sorunlar, kavramlar ve yeniliklere karşı İslam kültüründen gelebilecek cevaplar üzerine günümüze ışık tutacak ipuçlarını içinde barındırıyor.

Her ne kadar "Islami" bir çizgide eser verseler de dönemin tüm aydınları gibi onlar da esasen pozitivizme dayanan modern dünyanın ürettiği kavramlar ve düşünce araçlarından faydalanıyor. "Tecrübeye" dayanan bilim zihniyetiyle sosyal bilimlerin ayrı şekilde ele alınabileceği kanaatinden hareket ediyor. Bu üzerinde düşünmeye değer bir konudur. Geldikleri kültür itibariyle yerel ve ulusal unsurları değil İslam'ın evrensel mesajını ve ümmet bilincini esas alıyorlar. Öte yandan medeniyetin insanlığın ortak mirası olduğu noktasından hareketle insanlığın ortak değerlerini referans alıyorlar.

\section{Kaynakça}

\section{Belgeler}

BOA, I.DUIT.18 -79, H.16-02-1331 (1913). (Başbakanlık Osmanlı Arşivi, İrade Dosya Usulü ), Dosya No: 18, Gömlek No: 79, Hicri Tarih.

BOA, I.DUIT 8-80, H-18-02-1331.

BOA, HR. SFR. 3, 549-12, M-06-02-1905 (Hariciye, Londra Sefareti).

BOA, HR. SFR. 4, 279-58, M.23-10-1913 (Hariciye, Paris Sefareti).

BOA, HR. SFR.1, 169-46, M.14-06-1913.

BOA, HR. SYS. 2392-3, M.09.08.1914.

FO. Telegram, No: 1178, Dec.11.1917.

BOA HR. IM. 112-6 M-02-08-1924 (Hariciye Nezareti İstanbul Murahhaslığı).

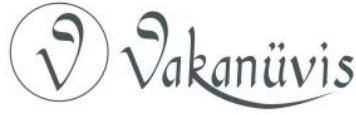




\section{Periyodik Yayınlar}

Bostan, M. Hanefi, Sait Halim Paşa ve Fikirleri, 21.Yüzyılda Eğitim ve Toplum 8/22, 2019,

Çabuk, Mustafa, İngiliz Belgelerine Göre İngiltere'nin Ortadoğu'daki İstihbarat Merkezi: Arap Bürosu (1916-1920), Belgi Dergisi, C.2, s.17, Pamukkale Ün.Yay., Kış 2019/1, ss.1130-1147.

Guida, Michelangelo, "The Life and Political İdeas of Grand Vezir Said Halim Pasha", Turkish Journal of Islamic Studies, 18 (2007), s.103.

Islamic Culture, 101, 1927, s.175. (3 Kasım 2020)

Kuran, Ercüment, Osmanlı İmparatorluğu'nda İslam Düşüncesinin Gelişmesi, Türk Kültürü, Eylül Ekim 1979, s. 203 - 204.

Muslim, Tory, "Conversion of Marmaduke Pickthall, Lawrence M. Stratton", Koinonia XVI (2004), s.78-100.

Pickthall, "The True Khilafat", The Islamic Review, XI, II (Nov.1923), s.391. (3 Kasım 2020)

Pickthall, Journal of the Central Asian Society, April 1936, s.221. (3 Kasım 2020)

Pickthall, New Age, 17 Nisan 1919, s.389 -391. (3 Kasım 2021)

Pickthall, New Age, 7 Kasım 1912, s.8. (3 Kasım 2020)

Saturday Review, Dec.8, 1917. (3 Kasım 2020)

Sebilürreşad, c.19, no:493, 26 Şubat 1338 (1922).

The Muslim Standart, Dec.22, 1921. (1 Kasım 2020)

The Nineteenth Century and After, December 1912, s.1147. (5 Kasım 2020)

Urquart, Davit, "The Comparison of Christendom with the Ottoman Empire", Diplomatic Review, April 3 - 1867, s.53. (5 Kasım 2021)

\section{Kitaplar}

Demolins, Edmond, À quoi tient la supériorité des Anglo-Saxons, Didot, Paris 1897; Anglo - Saxon Superiority: To What It Is Due?, The Leadenhall, London 1899; Anglosaksonların Esbab-ı Faikiyeti Nedir?, Araks Matbaası, İstanbul, 1914.

Fremantle, Anne, Loyal Enemy, Hutchinson, London 1938.

Inal, İbnulemin M. Kemal, Son Sadrazamlar IV 1893-1932, İst. 1982.

islam ve Yorum, C.III (Haz.Prof. Dr. Fikret Karaman), Malatya Illahiyat Vakfı Yay., Malatya 2017.

Kayalı, Hasan, Jön Türkler ve Araplar - Osmanlıcılık, Erken Arap Milliyetçiliği ve islamcılık 1908-1918, İş Bankası Yay. İstanbul, 2018.

Richards, Denis - J. W. Hunt, Illustrated History of Modern Britain 1877 1964, Longman, London 1977.

Ulubelen, Erol, Ingiliz Gizli Belgelerinde Türkiye, Aykaç Kitabevi, İst.1967.

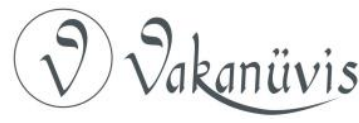


Kara, İsmail (Hazırlayan), Türkiye'de Islamcılık Düşüncesi I, Risale Yay., İstanbul, 1986.

Kahraman, Kemal, Muhammed M. Pickthall - Bir Ingiliz Yazarın Müslüman Olarak Portresi, İz Yay. İstanbul, 1995.

Kahraman, Kemal, Marmaduke W. Pickthall, DiA, C.34, İst. 2007, s. 270-271.

Kahraman, Kemal, W. S. Blunt, DiA C.6, İst. 1992, s.246-47.

Yiğiter, Kemalettin, William M. Pickthall'un Yakın Doğu ile IIgili Eserleri ve Türkler, Aktif Yay., İst.2007.

Pickthall, Marmaduke W., Doğuyla Karşılaşmalar (1894-1896), Çev. Yusuf Yazar, Büyüyen Ay Yay., İst. 2017.

Pickthall, Marmaduke W., Harpte Türklerle Birlikte (Çev. Kemalettin Yiğiter), Kültür Bakanlığı Yayınları, Ankara.

Pickthall, Marmaduke W., The Cultural Side of Islam (Islamic Culture), S.H. Muhammad Ashraf, Lahore 2000.

Pickthall, Marmaduke W., Islam and Progress, The Islamic Book Society, Lahore 1920.

Pickthall, Marmaduke W., Islam and the Modern World, Ed. Geoffrey P. Nash, Brill Leaiden/Boston 2017.

Ersoy, Mehmet Akif, Safahat, Hazırlayan Vahap Akbaş, İstanbul 2007.

Mevlanzade Rıfat, Türkiye Inkılabının Iç̧üzü, Hazırlayan Kemal Kahraman, Kaknüs Yay. İstanbul 2017.

Bostan, M. Hanefi, Bir İslamcı Düşünür: Said Halim Paşa, İrfan Yay., İst.1992.

Bostan, M. Hanefi, DiA, c.35, s.557-560.

Modern Türkiye'de Siyasi Düşünce - İslamcılık, İletişim Yay., İst. 2014.

İkbal, Muhammed, Cavidname (Çev. Prof. Anna Maria Schimmel), İz Yay. İst. 2010.

Mustafa Sabri Efendi, Hilafetin IIgasının Arka Planı, İnsan Yay., İstanbul 2013.

Kıdwai, Müşir Hüseyin, Paris Sulh Konferansı ve Osmanlı'nın Çöküşü, Sadeleştiren Ahmet Zeki İzgöer, Nehir Yay. İstanbul 1991, 158 s.

Pickthall, Marmaduke W., İlam Medeniyetinin Dinamikleri (Çev. Yusuf Kaplan), Külliyat Yay. İs.2018.

Said Halim Paşa, Buhranlarımız ve Son Eserleri, Hazırlayan M. Ertuğrul Düzdağ, İz Yay., İstanbul 2015.

Akşin, Sina, Jön Türkler ve İttihat ve Terakki, Remzi Kitabevi, İstanbul 1987.

Slade, Sir Adolphus, Müşavir Paşa'nın Kırım Harbi Anıları, Çev. Candan Badem, Türkiye İş Bankası Yay., İst. 2012.

Kocabaş, Süleyman, Türkiye ve Ingiltere, Vatan Yay., İst. 1985.

Mardin, Şerif, Jön Türklerin Siyasi Fikirleri (1895-1908), İletişim Yay., İst. 2015.

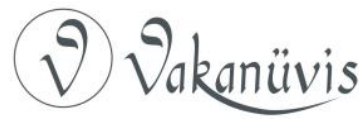


Karaca, Taha Niyazi, Sınırları Çizen Kadın Ingiliz Casus Gertrude Bell, Kronik, İstanbul, 2018. 